\title{
On a Better Understanding of the Threat Posed by Terrorism in Albania
}

\author{
Ruzhdi Kuçi \\ Rector at Armed Forces Academy of Albania
}

Doi: 10.2478/mjss-2018-0099

\begin{abstract}
This paper intends to provide a comprehensive description and differentiation of the terms terrorism, extremism and radicalization and to clarify that, though in everyday life and in various non-professional articles, they are frequently used interchangeably, they must be differentiated and clearly explained if we want to successfully prevent or, at least, to reduce the consequences posed by these threats. At the same time, this paper is an attempt to present the different ways described in the academic literature and political documents to define radicalization, violent extremism and terrorism, identifying the various characteristics of actors, individuals or organizations, seeking to engage in such activities as well as some ways to increase community capacity in taking appropriate steps to deal with root causes that can lead to violent actions.
\end{abstract}

Keywords: radicalization, extremism, violent extremism, terrorism

\section{Introduction}

Albania is located in the Western Balkans and borders with Greece, the Former Yugoslav Republic of Macedonia, Kosovo and Montenegro and it is separated from Italy to the West by the Adriatic Sea. It is a member of several important organizations, such as the United Nations, Council of Europe, Organization for Security and Cooperation in Europe, the Islamic Cooperation Organization and hopes for a near future membership in the European Union.

The use or threat or violence by different actors be they individuals, groups or organizations to achieve their political, economic, social or cultural goals, has become an issue of great concern all over the world. At present, these phenomena are not characteristic of Albania; however it is not immune from terrorism.

There are segments of the population worldwide, regardless of whether regimes are democratic or dictatorial, who feel that they are deprived of the rights belonging to them and to win these rights, they organize in secrecy, and are armed to achieve their objectives through force. Their actions are violent and cause heavy destruction and losses in human lives and material resources and assets.

Terms like terrorism, radicalism, extremism and violent extremism represent similar, but not identical concepts and create confusion for many people who are not able to distinguish between them. The use of these terms as though they are synonyms shows that the difference between them is not understood and consequently the policies, measures and procedures to fight against them may not be accurate and successful. As Jason-Leigh Striegher puts it "An individual who justifies the use of violence to achieve ideological, political, economic, social or religious goals in general suffers a kind metamorphose through a process of radicalization that leads to the adoption of violent extremism as an ideology, where terrorism is simply the act of violence undertaken to achieve these goals" (Jason-Leigh Striegher 2015) 


\section{Aim}

The aim of this paper, based on historical experiences, is to identify the differences and commonalities between radicalism, extremism, violent extremism and terrorism in order to give a modest help to determine how to prevent or, at least, to mitigate the consequences (risks) when these threats become real. Terrorism is spread throughout the world, but not all countries face the same level of threat. Though, according to 2011 census, about $70 \%$ of the Albanian population is Muslims (Census Albania 2011), still Albania is challenged by terrorist threats mainly because of being part of coalitions in war against terrorism. That is why, the article attempts to argue that Albania must be prepared to face terrorist challenges and threats.

\section{Differentiation between Radicalism, Extremism and Terrorism}

Radicalism is usually caused by inequality, discrimination and social, political and economic oppression, as well as disillusionment with the government. To be radical in and of itself is not a bad thing. One can be radical when he requires profound changes in society, thinking that society has enough flaws that need to be adjusted. Basically, radicalization does not necessarily lead to violence.

However, sometimes radicalization could be the start of a behavior that inclines toward extremism and terrorism. When transformed into extremism and radicalized individuals begin to use violence and to engage in illegal activities, it is transformed from a mere political concept into an issue for security.

Extremism is of various types, for example, religious extremism, national extremism, racial extremism etc. At the core of radical ideologies is extremism, radical religious beliefs, anger and frustration, which can lead to violence. Extremism implicates groups and individuals whose ideas go beyond the ideas of a normal society; therefore, they are a threat to society, causing consequences for certain groups or communities. Extremist groups can be found in all countries and religions.

Violent extremism is a more inclusive term than terrorism though in practice they are used equally. "Violent Extremism, as described by Jason-Leigh Striegher is the beliefs and actions of people who support or use violence to achieve ideological, religious or political goals. This includes terrorism, other forms of politically motivated violence and some forms of communal violence. All forms of violent extremism, no matter what their motivation, seek change through fear and intimidation rather than constructive democratic processes (Jason-Leigh Striegher 2015).

Resolution 2178 (2014) of the Security Council of the United Nations seeks to promote international cooperation in the fight against terrorism, stressing that "...that countering violent extremism, which can be conducive to terrorism... is an essential element of addressing the threat to international peace and security posed by foreign terrorist fighters". This interpretation considers violent extremism more as a different concept from terrorism rather than terms used interchangeably, although extremism is a possible way that brings to terrorism.

While the term "terrorism" has already received a contemptuous connotation, no one uses this term to identify their actions or the actions of their supporter. Insurgents / rebels who practice terrorism submit their actions as a war of liberation implying that they have to be recognized as soldiers, not as rebels or terrorists. They try to provide evidence to prove that their opponents who they consider as non-representative are real terrorists. For them, it is not actions, but the primary purpose that can be identified with terrorism. If the primary purpose is to achieve the denied rights, justice or, even more important, the liberation, the use of force to achieve them is not terrorism. On the other hand, maintaining an oppressive regime and injustice through state violence is clearly terrorism.

Likewise, there are governments that try to consider all actions of violence of the insurgents as different forms of terrorism. Official spokespersons and parts of media, mostly those supporting governments, presume that terrorism and terrorist actions are carried out by non-government elements, while the State does not make use of terrorism, though in practice there are States which either use terrorism or support or sponsor terrorist groups or organizations. According to them, 
terrorism can be identified not by the kind of actions carried out, but by who performs those actions. They consider that governments can use violence in wartime to defend their country and people, to ensure national interests and citizens' way of life. However when certain groups or organizations do the same, then they believe it is terrorism.

Terrorism is not an ideology; it is rather a strategy and tactics for achieving specific goals. It is generally understood as violence by groups with political, religious or ideological goals mainly aiming at intimidating and, in general, it also has other social, religious, economic and politic purposes.

Though there are some similarities between extremism and terrorism, there are changes between them that are important to identify in order to avoid misunderstandings or incorrect use. Maintaining extremist political positions do not necessarily mean terrorism. But when violent actions endanger normal functioning of society, human rights, democratic values and principles, rule of law and the democratic system of a country, no doubt, those actions are considered violent extremism.

According to political scholar Chris Hamilton, extremists should be distinguished from terrorists by their willingness to commit acts of violence. "In other words, all terrorists are extremists, but not all extremists are terrorists" (Hamilton, C. 2012). Neiwert thinks that "...extremism is politics and a culture that shuns dialogue and the democratic exchange of ideas in favor of the pursuit of outright elimination of the opposing side, either through suppression, exile, and rejection, or extermination. In the hard-sense, the difference between an extremist and a terrorist hinges upon the willingness to commit acts of violence against a group or individual (Neiwert, D. 2002). While extremists openly call for suppression, expulsion or elimination of a group or individual, they would not actually commit an act of physical violence. The call for such behavior in this sense is more a call for others to perform violence."1

How can we make the difference between ordinary criminals and the special case of terrorism? White argues that in distinguishing events, there is the need to identify major differences. Ordinary criminals (White, J. R. 2002) are often "opportunistic, uncommitted, self-centered," lack a clear cause, remain untrained, and are "escape oriented."

On the other hand, terrorists are "fighting for political objective, motivated by ideology or religion," are "group focused," ... and are "trained and motivated for the mission" at hand. ${ }^{3}$ Generally, while politics, security and media institutions discuss about terrorism they are mainly counting on international terrorism, forgetting or not paying proper attention to domestic terrorism. International and domestic terrorism have the same features; however, while domestic terrorism primarily operates within the country, international terrorism is carried out mainly outside the country or penetrates national borders with vehicles and people who commit terrorist acts. It should be noted that domestic terrorism is the most difficult and the most damaging kind of terrorism. For instance, when there are people with access to economic and military structures and complexes, who know Albania better than foreign terrorists they can cause more serious consequences. Violent terrorists and extremists operate not only in public places; they can exploit and utilize the Internet for their purposes, for radicalization and recruitment purposes to planning a terrorist attack.

\section{The Threat of Terrorism to Albania}

No country in Europe is immune from the threat of terrorism; the threat is possible, under certain conditions, is multifaceted and cannot be completely eliminated. However, it should be carefully evaluated in order to be sure that it is neither exaggerated nor minimized. Borders are penetrable. No wall can be as long and high to keep out the desperate, extremists and terrorists and not just small, weak or unstable countries, but even the great powers cannot have enough protection to monitor land, sea and air borders. This means that the solution is not closing borders and keeping the refugees away, the threat may come not only from the outside, but sometimes more from inside

\footnotetext{
${ }_{2}^{1}$ http://journalofidiocracy.blogspot.al/2012/05/defining-terrorism-and-extremism.html

2 White, J. R. (2002). Terrorism: An Introduction. Canada: Wadsworth Thomson Learning. http://journalofidiocracy.blogspot.al/2012/05/defining-terrorism-and-extremism.html ${ }^{3} \mathrm{lbid}$
} 
the country.

Albania is exposed to the potential threat of a terrorist attack. Albania is a small developing country, therefore national security institutions need the necessary time to gain the professional excellence and achieve institutional integration. Territorial, air and sea integrity, even the institutions and public and private property, are far from standardized security measures. Nonetheless, as a NATO member, Albania contributes to global peace and security. This is one of the main findings of Military Strategy in the Republic of Albania. The document defines threats to the Albanian state, among which the main threat is the new Islamic State (Military Strategy of the Republic of Albania, 2015).

Geographical position puts Albania at the map of transit of narcotics originating from Asia, and near the risks from instability in the Middle East and North Africa. The transfer of political conflicts, particularly those with religious grassroots, various trafficking and illegal immigration remains a major challenge for the country's security. Ideological, religious or nationalistic inspired extremism nourishes terrorist activities. The above mentioned document states that: "Extreme ideologies rely on ignorance, poverty, lack of services and multiple regional and international links " ". This document highlights that it is exactly these reasons, create the ground for recruitment of frangible individuals who participate in international conflicts. Due to the expansionary trend, extremism can pose a danger to the cohesion and values of the Albanian society and to the region.

\section{Main Forms of Threats}

The Albanian Military Strategy predicts that the threats and risks to the Republic of Albania, as a NATO member are assumed to be of conventional and unconventional nature. Terrorism poses a serious and imminent threat to international security, stability and prosperity. Religious extremist and criminal groups continue to spread in different areas of the globe, using unstable regions and failed states becoming a potential security threat. Modern technology of information and the opportunity of access of terrorist to chemical, biological, radiological or nuclear weapons have increased the threat of terrorist attacks. Regional tensions affected also by other ideological, political, religious and cultural factors can inspire extremist groups who aim at the spread of extremist ideologies, and undertaking terrorist acts in Euro-Atlantic area, including the Republic Albania. Recent developments in the southern wing of the Alliance make terrorism even a greater threat not only for Albania but also for the countries of the Alliance.

Organized crime and illegal trafficking will continue to pose a global, regional and national security threat. Military Strategy of Albania stresses that: "The trafficking of arms, drugs, human beings, hazardous materials, piracy, and cybercrimes do characterize transnational organized crime. International groups of organized crime can cooperate with failed states, with terrorist groups and they can use sophisticated networks, which pose a challenge to law enforcement agencies ${ }^{5 "}$. The country's security can be related to the malfunctioning of state institutions. Political instability is a risk for the security and protection of national interests. The so far democratic experience shows that a possible political instability threatens the normal functioning of institutions, peace and public security, as well as our national security.

Either for Albania or other countries, a great concern is the new threat posed by transit foreign fighters as refugees fleeing from Iraq, Syria and Afghanistan. There is no doubt that to prevent this threat one of the important issues is to be better informed and to better protect the borders. An important advantage available for Albania is access to $\mathrm{FBI}$ and the US National Centre data for the fight against terrorism. By the help of this tool, Albanian Border Police can read the list of thousands of potential terrorists composed in cooperation with dozens of partner countries ${ }^{6}$.

\footnotetext{
${ }^{4}$ Military Strategy of the Republic of Albania, 2015

${ }^{5}$ Ibid

${ }^{6}$ USA ambassador, Donald Lu, Tirana 2016 http://sot.com.al/politike/donald-lu-shqip\%C3\%ABria-e-rrezikuarnga-kalimi-i-terrorist\%C3\%ABve-asistenc\%C3\%AB-nga-fbi
} 


\section{How to Prevent Terrorism?}

There are a number of United Nations agreements on terrorism, which reflect the evolving nature of the threat. The United Nations global strategy ${ }^{7}$ against terrorism in 2006 , highlights prevention, and stresses the need to review the conditions conducive to the spread of terrorism. The best way to prevent terrorism is to disallow people become terrorists. Terrorist and extremist groups and their networks promote violent extremism in a number of ways. Their continuous existence is based on recruiting others for the benefit of their cause. There is not a typical profile which type of person is at risk of being attracted by violent extremism, but it is obvious that family, friends and colleagues are the first to notice the signs that an individual is being involved in violent extremism. Experience shows that ultimately people and communities are those who defeat terrorism. They can help in the prevention of terrorism by staying alert to suspicious actions and report any misgiving attitude.

Terrorists need time to plan and prepare their attacks and must live in a certain place. It is a fact that some types of activities may be indicators of terrorist plans, especially when they are manifested in or in the vicinity of places with large crowds of people, such as government buildings, military installations, bus and train stations, massive public events etc. Such indicators for terrorists might be: purchase and storage of materials in certain places; financing different activities; provision of equipment and weapons; conduct of training; people who come and go at an unusual time of day or night; use forged documents to hide true identity; using cameras, maps, binoculars in the vicinity of major installations; collecting information by asking others, by phone or e-mails, about key installations; unlawfully providing explosives, guns, ammunition, dangerous chemicals and specific uniforms.

Albania is a country where the majority of population belongs to Islam faith and a special characteristic of different faiths in Albania is their early and continuous coexistence with each other. On the other hand the Muslim population in Albania in terms of mentality and way of life belongs to European culture. Indifference to religion is another feature of Albanians, based on the belief that Albanians have a strong sense of nationality that leaves aside all the other differences between them, including religion.

Religion has had a very important role in the creation of national identities in Europe. In many countries, especially in those with Muslim majority, religion is connected with national identity. Albania has a Muslim majority, but because of indifference towards religion, the Albanian national identity is not affected by religion. The writer and publisher of the Albanian National Renaissance, Pashko Vasa writes: "The religion of Albanians is Albanianism!"8

At the international conference on foreign terrorist fighters and routes of irregular migrants, was held in September 2016 in Durres, Albania's Deputy Prime Minister, Niko Peleshi stressed the need for a multi-dimensional action, as he announced the implementation during this school year of a pilot program which intends to provide students with some knowledge based on religion and religious coexistence and to prepare young people to cope with extremist pressures. Along with the secular character of the state and school, the strategy aims to fill the vacuum created over the years on issues of civic education regarding religion"

Religion can be part of secular education in public schools in terms of not teaching religion but about religion. Quran or the Bible can be taught in school, but only for the role of religion in historical, cultural and literary development in Albania, in order to instill understanding, tolerance and respect for a pluralistic society. Religion should be discussed in a neutral, objective, balanced and factual way. The teaching program on religion should educate students with the principles of religious freedom, as one of the fundamental principles of freedom and democracy in the country and never for purposes of devotion, prayer or doctrinal, or to encourage acceptance of the Bible or the Koran as a religious document.

The teaching of religion means indoctrination and religious practice and is clearly banned in public schools. This kind of teaching cannot promote or denigrate a particular faith, faith as a whole

\footnotetext{
${ }^{7}$ https://www.un.org/counterterrorism/ctitf/en/un-global-counter-terrorism-strategy

${ }^{8} \mathrm{O}$ moj Shqypni, Poezi nga Pashko Vasa, 1880 http://www.teksteshqip.com/pashko-vasa/poezi-101206.php

${ }^{9}$ http://time.ikub.al/16-09-15-Te-infiltruarit-mes-refugjateve-rrezik-per-terrorizem-ne-Ballkan
} 
or lack of faith. Students could be encouraged to accept or refuse specific beliefs and religious practices. A teaching program that aims at teaching religion, disguised as teaching about religion should be considered unconstitutional.

Apart from the above, the teaching of religion should be treated with care to avoid the impression of linking religion with terrorism, which would create harmful misunderstandings and will not really serve the purpose of preventing, alleviating or coping with violent actions.

\section{Conclusions}

The state has the obligation and bears the primary responsibility, in order that through policies, creation and effective use of security and international cooperation agencies, through the exchange of information and coordination of concrete activities, to prevent and, when that is not possible, to tackle efficiently the violent and terrorist actions, to save people's lives and public and private property, and to ensure respect for and protection of human rights and fundamental freedoms.

As different countries are trying to find more efficient ways to prevent terrorism, at the same time we notice an increase of efforts to understand why and when individuals turn to terrorism, how does it happens and the ways it can be prevented since the very beginning.

The international community has repeatedly stressed that strongly condemns terrorism in all forms and the ways it manifests itself, by anyone, anywhere and for any purpose, as one of the most serious threats to peace and security worldwide.

At the same time, the international community has strongly rejected the identification of terrorism with any nationality, religion or an ethnic affiliation. However, the state needs to ensure the support of society in general, including civil society, non-government actors and businesses, to fight this phenomenon successfully.

\section{References}

Strategjia Ushtarake e Republikës së Shqipërisë, 2015 http://www.mod.gov.al/images/PDF /strategjiaushtarakeRSH.pdf

UN Strategyoncombatingterorism, Document A/RES/60/288, 2006, <http://www.un.org/en/terrorism/strategycounterterrorism.shtml>.

OSCE, CouncilofMinisters, "CharteronPreventingandCombatingTerrorism", Porto, 2002 $<$ http://www.osce.org/odihr/16609>.

Hamilton, C. (2012), Personal Interview. Topeka, KS: WashburnUniversity.TheJournalofldiocracy http://ro.ecu.edu.au/cgi/viewcontent.cgi?article=1046\&context=asi

White, J. R. (2002). Terrorism: An Introduction . Canada: WadsworthThomsonLearning. http://journalofidiocracy.blogspot.al/2012/05/defining-terrorism-and-extremism.html

SecurityCouncilResolution 2178 (2014) http://www.un.org/en/sc/ctc/docs/2015/SCR\%202178_2014_EN.pdf

Neiwert, D. (2002). The Eliminationists: How Hate Talk Radicalized the American Right . Sausalito, CA: PoliPointPress, LLC. http://journalofidiocracy.blogspot.al/2012/05/defining-terrorism-and-extremism.html

Jason-Leigh Striegher, Violent-extremism: An examination of a definitional dilemma 2015 http://ro.ecu.edu.au/cgi/viewcontent.cgi?article=1046\&context=asi2015

Census Albania $2011 \mathrm{http}: / / \mathrm{www}$. instat.gov.al/en/census/census-2001/census-data.aspx

Charles C. Haynes: A Teacher's Guide to Religion in the Public Schools http://www.religiousfreedomcenter.org/wp-content/uploads/2014/08/teachersguide.pdf 